\title{
WADAH SENI KOLEKTIF SENEN
}

\author{
Samuel Axel Widjaya ${ }^{1)}$, Nina Carina ${ }^{21}$ \\ 1)Program Studi S1 Arsitektur, Fakultas Teknik, Universitas Tarumanagara, samuelAW98@gmail.com \\ 2)Program Studi S1 Arsitektur, Fakultas Teknik, Universitas Tarumanagara,ninac@ft.untar.ac.id
}

\begin{abstract}
Abstrak
The 3rd place merupakan tempat penting yang dibutuhan masyarakat, selain dari rumah sebagai the $1^{\text {st }}$ place maupun tempat kerjanya sebagai $2^{\text {nd }}$ place. $3 r d$ place adalah ruang publik yang netral, sebagai tempat alternatif. Setiap orang dapat berkunjung dan melakukan berbagai aktivitas. Sebuah $3 r d$ place dapat memiliki bentuk yang beragam, namun nyaman untuk beraktivitas sesuai dengan kehidupan dan budaya masyarakatnya. Kawasan Senen sejak dahulu dikenal sebagai pusat perdagangan dan kesenian yang cukup ramai. Hal ini dapat dilihat dari sejarah kawasannya yang menjadi tempat lahir beberapa seniman terkenal tanah air. Dibangunnya Taman Ismail Marzuki (TIM) pada 10 November 1968 membuat nilai seni di Kawasan Senen ini sempat luntur. Namun seiring waktu, nilai seni dari Kawasan Senen mulai kembali naik. Hal ini ditandai dengan beberapa aktivitas berunsur seni yang mulai dilaksanakan kembali di Kawasan ini seperti pertunjukan Wayang Orang Bharata Purwa yang rutin diadakan setiap hari Sabtu sampai kursus menari tradisional yang diadakan secara gratis oleh Museum Kebangkitan Nasional dan juga munculnya Komunitas Planet Senen (KOPS) yang kerap berusaha memperkenalkan unsur seni kepada masyarakat Senen. Proyek Wadah Seni Kolektif Senen ini bertujuan untuk menjadi wadah $3^{\text {rd }}$ place bagi warga serta memfasilitasi dan memperkuat kembali unsur seni di Kawasan Senen ini.
\end{abstract}

Kata Kunci: Ruang Publik Netral; Seni Kolektif; Seni Senen; Tempat Ketiga

\begin{abstract}
A 3rd place acts as an vital place in our daily life, aside from home as the 1st place or workplace as the 2nd place. 3rd place is a neutral public space, often seen as an alternative for some people. Everyone is welcome to visit and to do lots of activities on it. A 3rd place doesn't have a fixed form, it can be anything the community around it needs it to be.Kawasan Senen was known as the centre of trade and art since forever. It can be seen from its history that became the birthplace of some of the finest artists in Indonesia. When Taman Ismail Marzuki was built on November 10th, 1968, the value of art in Kawasan Senen began to fade. But as time goes by, the value of art in Kawasan Senen begins to rise again. This event can be seen by the rise of art activities around Kawasan Senen such as Wayang Orang Bharata Purwa show that runs every Saturday, the free traditional dance classes that were held by Museum Kebangkitan Nasional and the emergence of Komunitas Planet Senen (KOPS) that actively trying to reintroduce the value of art to the Senen community. Senen Collective Art Space project was built on the hope to become the 3rd place to the community as well as providing and strengthening the value of Kawasan Senen.
\end{abstract}

Keyword: Art in Senen; Collective Art; Neutral Public Space; Third Place 


\section{PENDAHULUAN}

\section{Latar Belakang}

Rutinitas warga Senen Jakarta Pusat yang berlarut mengikis faktor sosial dari masyarakat dan mengubah pola kehidupan mereka dalam menghadapi tekanan dari luar seperti tekanan pekerjaan, dan lainnya. Kawasan Senen dulunya merupakan tempat lahirnya Seniman Senen. Kawasan Senen juga sudah dikenal sebagai pusat perdagangan dan kesenian yang cukup ramai. Lalu pada tahun 1930 muncul anak- anak muda dari seantero Nusantara yang sering bercengkerama di daerah Senen ini yang kebanyakan merupakan mahasiswa, aktivis, dan pejuang bawah tanah.

Pada tahun 1968, Gubernur Jakarta saat itu Ali Sadikin memutuskan untuk membangun TIM yang diharapkan akan menjadi pusat seni baru bagi para seniman-seniman di Jakarta. Hal ini menyebabkan nilai seni di Kawasan Senen ini perlahan luntur (Biran, 2008). Dewasa ini, nilai seni di Kawasan Senen sudah mulai luntur. Namun usahan Kawasan Senen untuk kembali menaikkan nilai seni ini dapat dilihat mulai dari pertunjukan Wayang Orang Bharata Purwa yang diadakan setiap hari sabtu termasuk juga kursus menari yang diadakan secara gratis oleh Museum Kebangkitan Nasional. Namun usaha tersebut belum mampu secara maksimal menaikkan kunjungan warga Kawasan apalagi wisatawan dalam maupun luar negeri. Oleh karena itu, proyek Wadah Seni Kolektif Senen ini diharapkan dapat menampung warga Kawasan Senen dengan berbagai program yang dibutuhkan terutama oleh warga sekitar.

\section{Rumusan masalah}

a. Apa saja rutinitas warga Senen yang mampu mempengaruhi kadar sosial masyarakat?

b. Bagaimanakah usulan program third place yang sebenarnya, sehingga mampu menampung kegiatan warga Senen?

c. Desain seperti apakah yang mampu menampung dan sesuai dengan potensi dari Kawasan Senen?

\section{Tujuan dan Manfaat}

a. Mengembalikan popularitas Kawasan Senen sebagai pusat seni yang ramah akan orang awam.

b. Mengedukasi generasi baru akan nilai Seni yang tertanam di Kawasan Senen.

\section{KAJIAN LITERATUR}

\section{Open Architecture}

Yi Fu Tuan (1977) berpendapat bahwa ruang lebih abstrak dari tempat. Pendapat ini didasarkan pada kondisi dimana setelah mengalami sebuah ruang, maka individu bisa menangkap nilai - nilai yang hadir di ruang tersebut. Dengan kata lain tempat ditentukan berdasarkan suatu kondisi tertentu yang hadir di sebuah ruang. Ini berarti tempat hanya bisa hadir apabila ada ruang sebagai dasar pembentukannya. Namun De Certeau (1984) memiliki pendapat yang berbeda dimana ia justru mengemukakan bahwa 'space is practiced place'. Ini berarti bertolak belakang dari apa yang dikemukakan Yi Fu Tuan, dimana tempat justru menjadi dasar dari kehadiran sebuah ruang. Ruang bisa hadir dari tempat layaknya kata - kata yang kemudian diucapkan, maknanya bisa berbeda tergantung berbagai situasi dan kondisi yang ada.

Lefebvre (1991) memperkenalkan istilah ketiga dan berargumen bahwa space dimengerti sebagai lansekap fisik dan sosial yang diilhami dengan pengertian dalam praktik sosial setiap harinya dan muncul melalui proses yang beroperasi melalui ruang yang bervariasi dan skala temporer. Tiga skala berbeda dikategorikan. Pertama, perceived space, yang termasuk gelembung emosional dan perilaku yang mengelilingi orang secara transparan dan organisasi 
sosial kompleks yang membentuk action spaces dalam rumah tangga, bangunan, lingkungan rumah, desa, kota, negara, ekonomi global, dan politik. Kedua, ruang yang kita ketahui sebagai spaces yang diproduksi oleh kekuatan dan ideologi oleh professional seperti perancang kota, insinyur, periset, dll. Dan akhirnya, tempat ketiga adalah spaces di mana semua ruang berada dan di mana subjektivitas dan objektivitas, abstrak dan konkrit,dan lainnya bertemu.

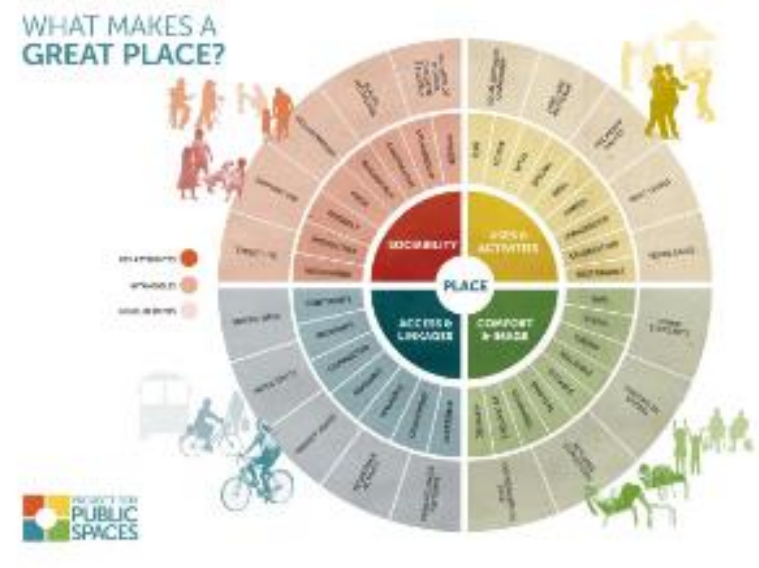

Gambar 1. What makes a great place? Sumber: pps.org

\section{$3^{\text {rd }}$ Place}

Dalam sebuah komunitas, $3^{\text {rd }}$ place adalah lingkungan sosial yang terpisah dari dua lingkungan sosial biasanya yaitu rumah (1st place) dan tempat kerja $\left(2^{\text {nd }}\right.$ place). Sebagai contoh lingkungan $3^{\text {rd }}$ place adalah gereja, kafe, klub, perpustakaan publik, toko buku, atau taman. Dalam bukunya The Great Good Place, Ray Oldenburg berargumen bahwa $3^{\text {rd }}$ place merupakan hal penting bagi komunitas publik, demokrasi, keterlibatan warga, dan membangun hubungan dengan sebuah tempat. Ray Oldenburg (The Great, Good Place: 1997). menyebutkan 1st place sebagai rumah. 2nd place merupakan tempat bekerja - dimana orang menghabiskan sebagian dari waktunya. 3rd places, merupakan "anchors" dari kehidupan komunitas dan memfasilitasi dan meluaskan interaksi kreatif lebih lagi. Dengan kata lain, 3rd place merupakan tempat untuk bersantai di publik, dimana anda menemui muka familiar dan membuat teman baru.

Menurut Ray Oldenburg menyatakan beberapa syarat tentang terbentuknya 3rd place yaitu bersifat netral yang berarti third place tidak terikat unsur finansial, politik, hukum, dan lain lain. Bersifat setingkat berarti tidak adanya hierarki yang memandang latar belakang dan status sosial. Memiliki kegiatan utama berupa percakapan antar orang, tempatnya mudah diakses, memiliki pengunjung tetap, dan bersifat menyenangkan. Robert Putnam menyampaikan isu yang berhubungan dengan $3^{\text {rd }}$ Place dalam bukunya Bowling Alone: America's Declining Social Capital $(1995,2000)$.

\section{Pentingnya $3^{\text {rd }}$ Place}

Dalam bukunya, ahli sosiologi Robert D. Putnam (Bowling Alone: The Collapse and Revival of American Community: 2000) mengingatkan bahwa kita telah semakin terputus dari keluarga, teman, tetangga, dan struktur demokratik kita. Putnam mengingatkan bahwa cadangan kapital sosial -penghubung antara satu dengan yang lainnya- telah menurun, menurunkan kualitas hidup dan komunitas. Berdasarkan bukti yang melibatkan lebih dari 500.000 wawancara selama seperempat abad belakangan, menunjukan bahwa masyarakat jarang mengikuti petisi, jarang mengikuti organisasi, jarang mengenal tetangga sendiri, jarang bertemu dengan teman, dan bahkan jarang bersosialisasi dengan keluarga. Putnam menunjukan bahwa perubahan 
pada pekerjaan, struktur keluarga, umur, televisi, computer, dan hal lainnya tutur berperan dalam hal ini.

\section{Hal yang Berkaitan dengan $3^{\text {rd }}$ Place}

Charles Montgomery (Happy City: 2013) mengatakan bahwa Urban Design atau pembentukan desain sebuah kota dapat mempengaruhi kesenangan atau mood orang yang tinggal di dalamnya. Dalam buku ini, setidaknya ada 7 kunci untuk membentuk sebuah "Happy City", antara lain City Suburban Sprawl, Banning Cars and Top Maintenance Keep Public Spaces Appealing, Parks That are Small but Dense and Diverse Make Urban Residents Happiest, Crowdedness Makes City-Dwellers More Private, Urban Design Decisions are Not Immune To Poor Planning, Self-Propelled Mobility Makes People Happier, Urban Planning That Redistributes Resources To The Less Privileged.

\section{Seni Kolektif}

Ranah seni pada hakikatnya merupakan sebuah hal kompleks yang mengandung hubungan agen-agen seni.hubungan antaragen ini erat satu sama lainnya dan masing-masing memiliki posisi pada struktur dan fungsinya. Pada masa pasca kemerdekaan, mulai bermunculan sanggar-sanggar seni yang menampung berbagai kegiatan seni. Seni dinilai sebagai alat bagi partai-partai politik untuk saling beradu. Pada masa ini pula mulai bermunculan akademi seni seperti Akademi Seni Rupa Indonesia (ISI Yogyakarta) dan Balai Pendidikan Universiter Guru Gambar (FSRD ITB). (Elok Santi Jesica, 2019, 1:76). Di dalam dunia seni rupa, ada yang disebut dengan kolektif, yakni sekumpulan penggiat seni yang bekerja atas kesamaan minat. Pada umunya, kolektif seni rupa bekerja secara independen dengan mengusung semangat tinggi dan menggagas praktik kolaborasi dengan menggabungkan ilmu lain di luar seni. Seni kolektif sendiri merupakan sebuah karya seni yang tercipta dari hasil kerjasama antara lebih dari satu orang. Seni kolektif dimulai dari dua atau lebih orang berkolaborasi untuk mengeksekusi sebuah tujuan yang sama.

\section{Seni Teater sebagai Seni Kolektif}

Teater merupakan sebuah bentuk kesenian yang diwujudkan dalam permainan sebuah tokoh dengan aktingnya dalam sebuah cerita melalui beberapa adegan. Adegan-adegan ini menggambarkan sebuah peristiwa baik fiksi maupun sejarah nyata. Seni teater disebut juga sebagai seni kolektif karena pada hakekatnya melibatkan banyak orang dalam produksinya. Seni teater sendiri merupakan kolaborasi dari tiga disiplin ilmu yaitu seni tari, seni musik, dan juga seni peran.

\section{Senen Pasca Kemerdekaan}

Pasca kemerdekaan Indonesia, masyarakat dari seluruh penjuru Indonesia mulai berdatangan ke pusat ibukota untuk mengadu peruntungan. Daerah Pasar Senen, yang tadinya didominasi oleh orang keturunan China, menjadi penuh oleh orang-orang Batak, Jawa Barat, Padang, dan Batak. (Merrillees, 2015). Saat itu, Kawasan Senen menjadi tempat berkumpul bagi banyak orang seperti gelandangan, pedagang, pekerja konstruksi, pelacur, kriminal, sampai Seniman. Area ini disebut juga sebagai Planet Senen. Planet Senen menjadi terkenal sebagai tempat berkumpulnya seniman-seniman dari seluruh Indonesia. Orang-orang ini disebut sebagai Seniman Senen. Planet Senen menjadi sebuah tempat berkumpul seniman yang akhirnya melahirkan beberapa bintang-bintang besar tanah air. (Biran, 2005)

\section{Lunturnya Seni di Senen dan Kebangkitan Kembali}

Pada tahun 1962, Gubernur Jakarta pada saat itu, Ali Sadikin, menggagaskan usulan Proyek Senen. Beliau membangun Taman Ismail Marzuki yang fungsinya untuk menggantikan Planet Senen sebagai pusat seni di Jakarta. Semenjak hal itu, mereduplah citra Senen sebagai pusat 
seni. (Merrillees, 2015). Namun seiring waktu, nilai seni dari Kawasan Senen mulai kembali naik. Hal ini ditandai dengan beberapa aktivitas berunsur seni yang mulai dilaksanakan kembali di Kawasan ini seperti pertunjukan Wayang Orang Bharata Purwa yang rutin diadakan setiap hari Sabtu sampai kursus menari tradisional yang diadakan secara gratis oleh Museum Kebangkitan Nasional dan juga munculnya Komunitas Planet Senen (KOPS) yang kerap berusaha memperkenalkan unsur seni kepada masyarakat Senen.

\section{Komunitas Planet Senen}

Komunitas Planet Senen (KOPs) merupakan sebuah 'Komunitas Seni dan Budaya' yang berusaha untuk memperkenalkan seni ke masyarakat Senen. KOPs didirikan pada tanggal 28 April 2008 sebagai benang merah penyambung generasi "Seniman Senen". Pada ulang tahunnya yang pertama, KOPs menyelenggarakan sebuah program bernama "Snenan" dengan konsep dasar "seni yang melibatkan masyarakat". Mereka bertujuan untuk membuat Senen menjadi sebuah wadah ekspresif dalam proses kreatif bagi masyarakat.

\section{METODE}

Metode perancangan yang digunakan adalah Narrative Architecture oleh Nigel Coates. Metode ini dimulai dari identifikasi permasalahan dan persoalan yang terdiri dari investigasi Kawasan dengan cara melakukan observaasi secara langsung dan dari data-data yang ada. Ekplorasi data mencakup berbagai macam sumber dari kajian literatur dan lainnya. Lalu dari data yang ada maka diterapkan ke dalam program dan konten sehingga membentuk sebuah ruangan yang bisa memberikan pengalaman ruang yang imersif. Dalam proyek ini, proyek didasari oleh sejarah seni yang ada dari Kawasan Senen itu sendiri.

\section{DISKUSI DAN HASIL}

\section{Jejak Seni Senen}

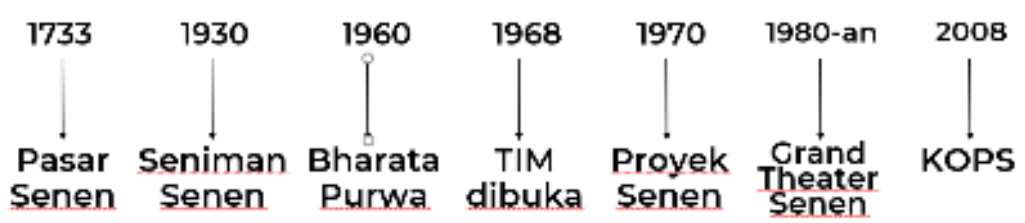

Gambar 2. Jejak Seni Senen

Sumber: Penulis, 2020

\section{Kondisi Kawasan}

Senen masih merupakan pusat perdagangan di Jakarta Pusat, ditandai dengan adanya Pasar Senen yang terbentang dari Blok 1 hingga Blok 6 . Kawasan Senen mengandung nilai budaya, seni, dan sejarah yang tinggi ditandai dengan adanya Wayang Orang Bharata Purwa, Grand Theater, dan Museum Kebangkitan Nasional (Badan Pusat Statistik: 2019). 


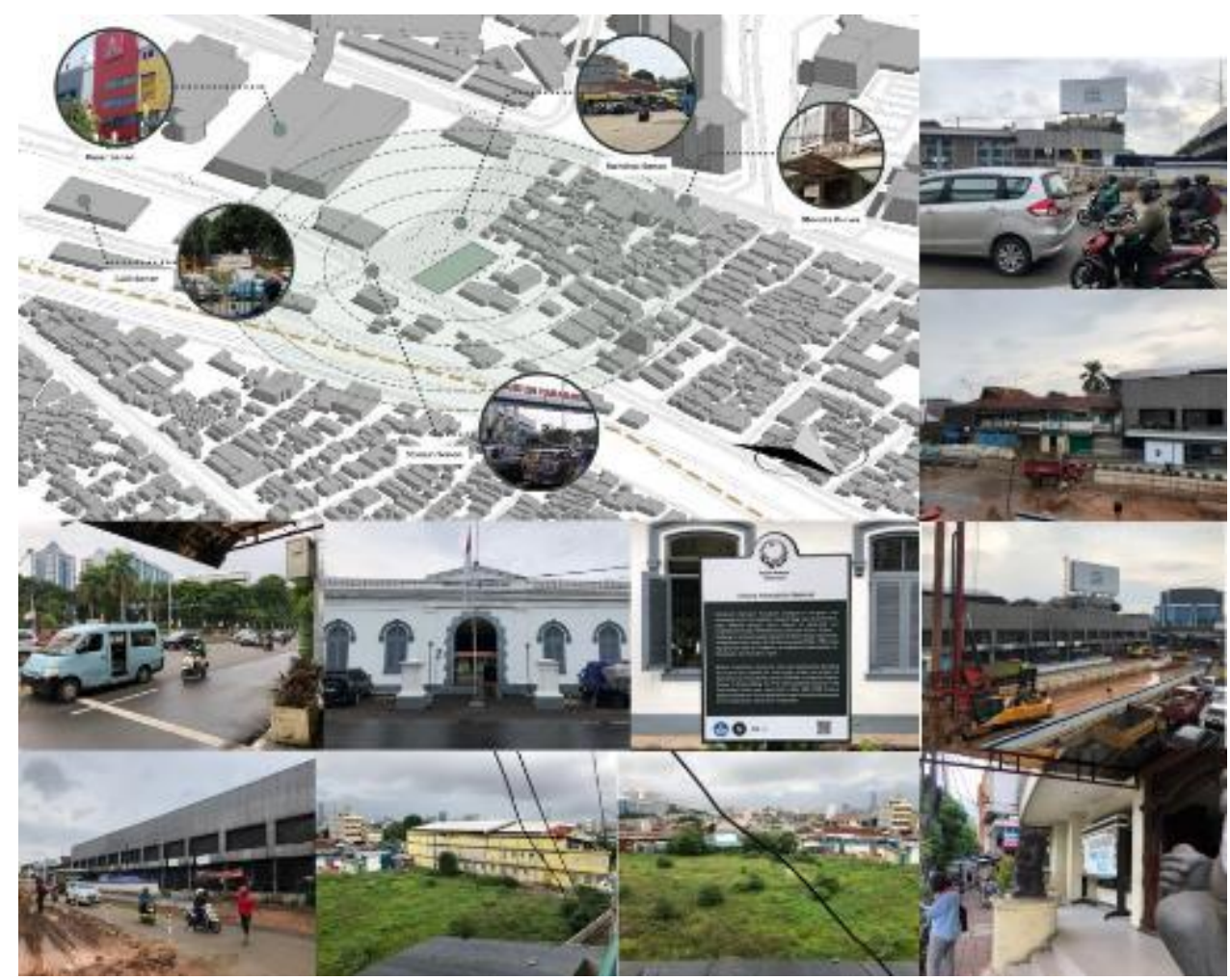

Gambar 3. Kondisi Kawasan

Sumber: Penulis, 2020

\section{Karakter Kawasan}

Karakter Kawasan Senen dapat dilihat dari jenis kegiatan yang banyak terjadi di Kawasan ini, diantaranya adalah kegiatan perdagangan, acara warga (dangdutan), kelas menari tradisional, rumah makan informal, sampai pertunjukan Wayang Orang Bharata Purwa yang rutin diadakan.

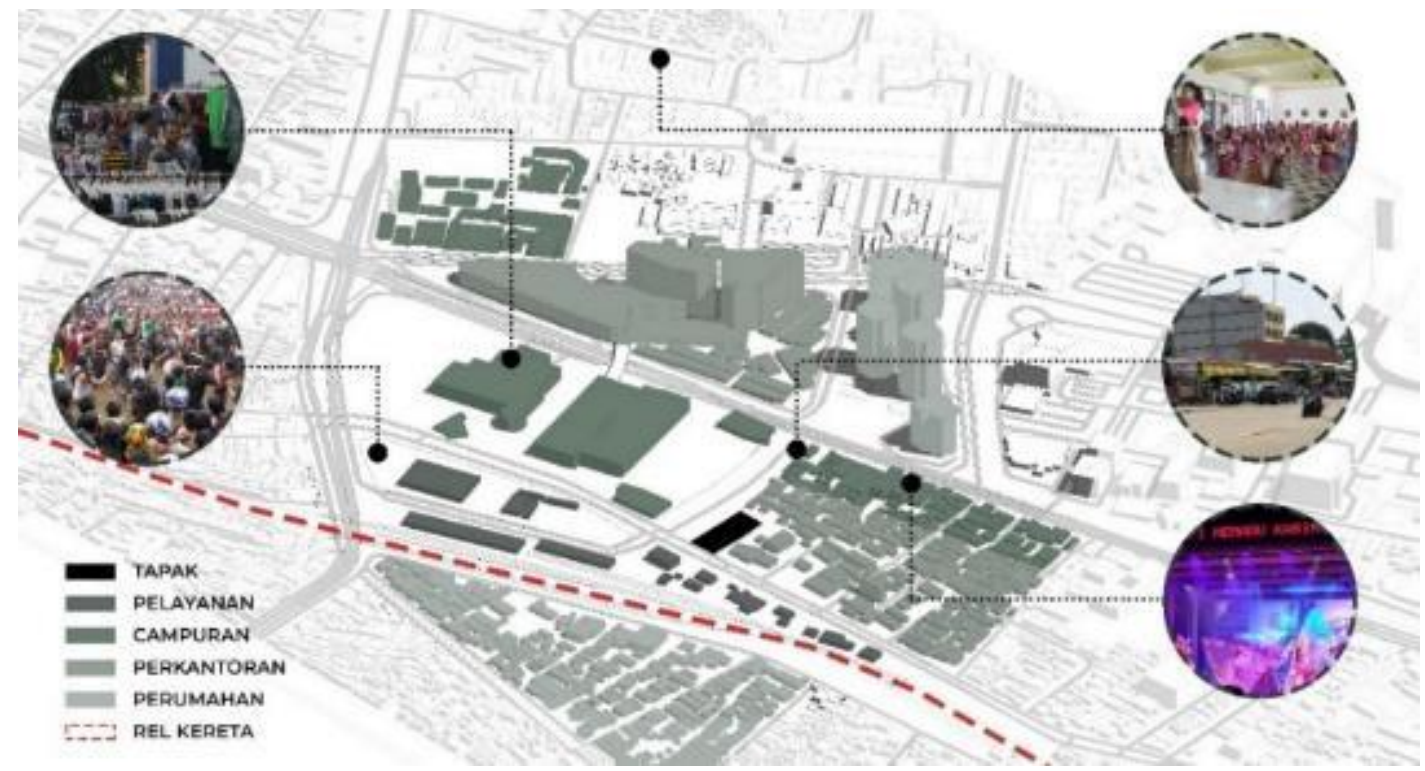

Gambar 4. Kondisi Kawasan

Sumber: Penulis, 2020 


\section{Program Kegiatan}

Program kegiatan yang terdapat dalam proyek Wadah Seni Kolektif Senen. Analisis ini bertujuan untuk mengetahui kegiatan yang terjadi pada bangunan serta pelakunya sehingga diperoleh ruang-ruang ynag diperlukan untuk mewadahi kegiatan oleh para pelaku.

Identifikasi kegiatan meliputi program-program yang ada pada proyek. Program-program tersebut antara lain sebagai berikut:

a. Kegiatan Pameran Diorama

Ruang diorama bertujuan untuk memberitahu kepada pengunjung suasana, kostum, dan kejadian yang terjadi dalam kisah perwayangan yang menjadi tema yang diangkat pada bangunan ini.

b. Kegiatan Komunitas

Ruang-ruang komunitas seperti open-air theatre dan lainnya menjadi tempat bagi para pengunjung untuk berpartisipasi pada kegiatan komunitas yang ada.

c. Kegiatan Sanggar

Ruang sanggar betujuan untuk menampung kegiatan-kegiatan seni yang muncul namun tidak dapat terwadahi dengan baik di Kawasan Senen ini.

d. Kegiatan Pameran

Menjadi tempat untuk mendisplay karya-karya perwayangan dan juga merepresentasikan wayang orang dengan bentuk yang lebih modern dan terkini.

e. Kegiatan Pentas Teater

Ruang teater merupakan tempat untuk menampung pertunjukan dengan jumlah masa yang banyak dan settingan panggung yang lengkap.

\section{Pengalaman Ruang yang Ingin Diciptakan}

Lukisan

Kisak Kresna Duta (Perang Bharata Vuda)
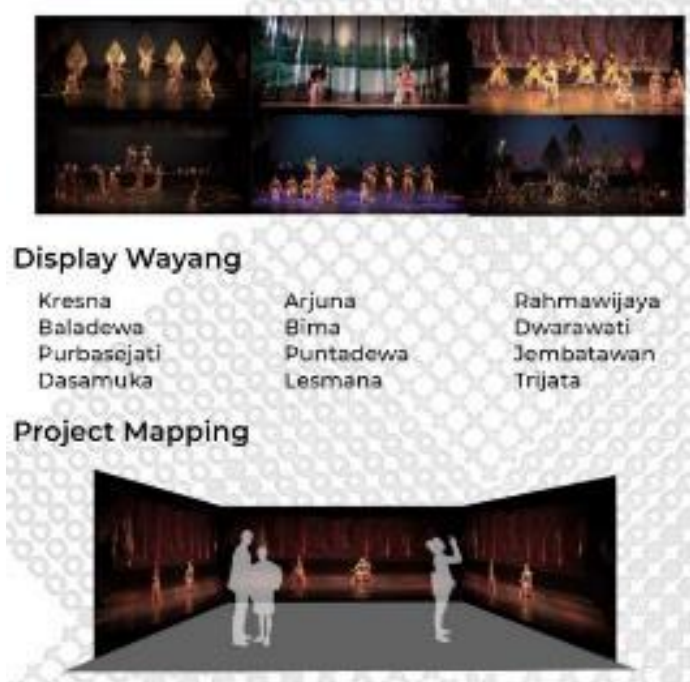

Diorama

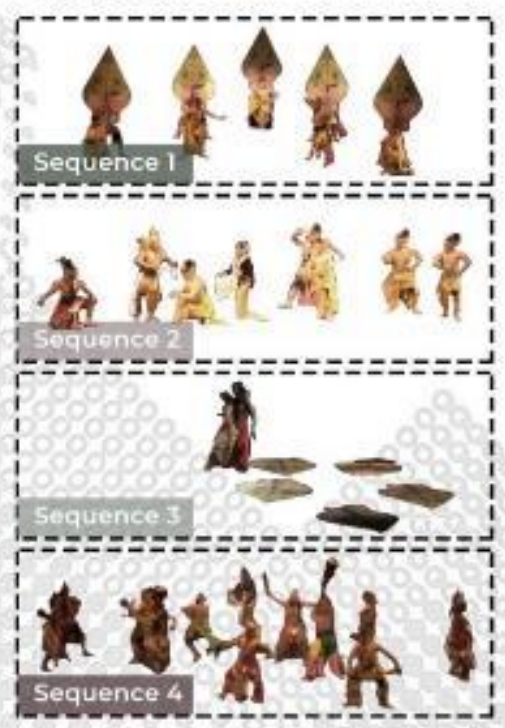

Gambar 5. Fleksibilitas Program

Sumber: Penulis, 2020

Alur dari perancangan diatur sedemikian rupa mulai dari lobby sehingga pengunjung dapat memahami sejarah seni wayang orang melalui ruang-ruang interaktif seperti ruang diorama. Lalu terdapat juga ruang pameran yang menampilkan video mapping supaya pengunjung dapat merasakan seperti berada di dalam pertunjukan wayang orang. Kemudia pengunjung diajak untuk menikmati pertunjukan Wayang Orang langsung di theatre bagian atas. Diagram diatas menunjukkan pengalaman ruang yang ingin disampaikan kepada pengunjung. 


\section{Program yang diusulkan}

Setelah melalui berbagai proses analisis aktivitas, tapak, dan konsep perancangan, maka dihasilkan kebutuhan ruang sebagai berikut

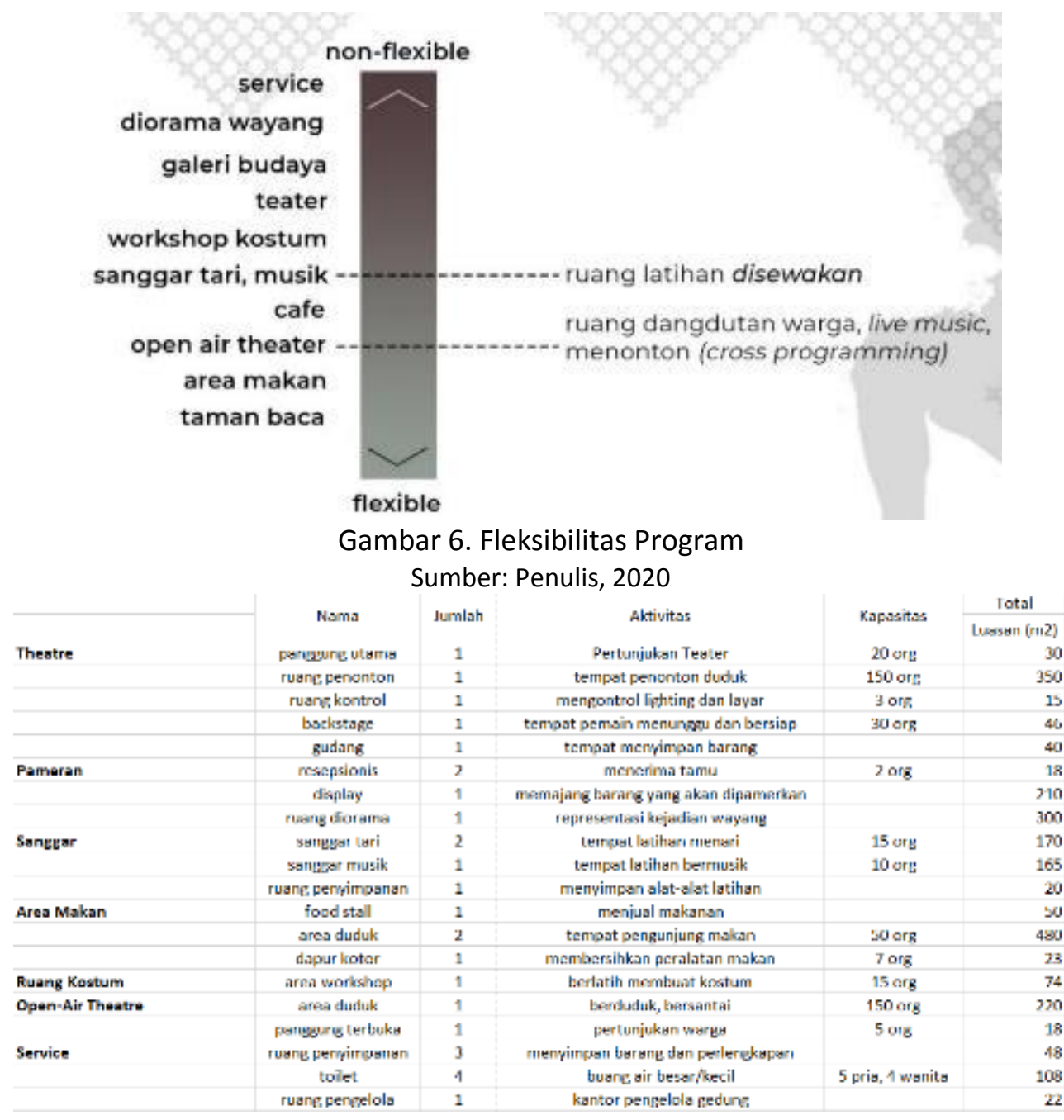

Gambar 7. Program Ruang

Sumber: Penulis, 2020

Dari tabel di atas, didapatkan total luasan proyek dengan keterangan sebagai berikut:

Total luas terbangun $\quad: 3.867 \mathrm{~m} 2$

KDB

\section{Konsep Desain Bangunan}
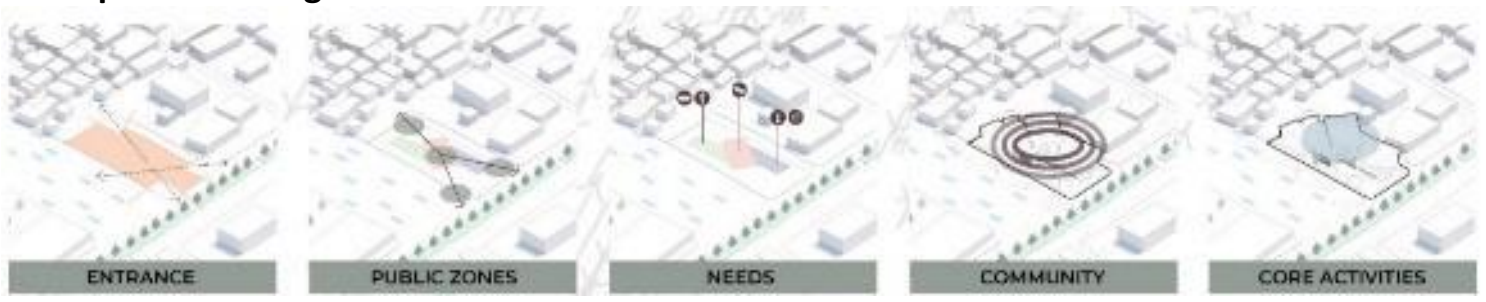

Gambar 8. Skema Desain

Sumber: Penulis, 2020 
a. Entrance

Entrance pada bangunan diletakkan di titik-titik dimana banyak sumber pedestrian pada daerah tersebut. Hal ini diharapkan dapat membawa lebih banyak orang untuk masuk ke dalam bangunan.

b. Permeability

Lantai dasar pada bangunan dibuat untuk menembus ke entrance manapun sehingga menyiptakan kontinuitas pada program bangunan.

c. Peletakan Program

Peletakan program pada bangunan disesuaikan dengan kebutuhan warga sekitar. Hal ini dilakukan agar proyek dapat menjadi tujuan bagi para warga sekitar.

d. Pusat Komunitas

Proyek menjadi sebuah pusat kegiatan komunitas dengan program-program yang mendukung seperti open-air theatre, dan lainnya.

e. Kegiatan Utama

Kegiatan seni menjadi program utama yang ada di bangunan dan sebagai daya tarik utama dari proyek.

\section{Proses Desain}

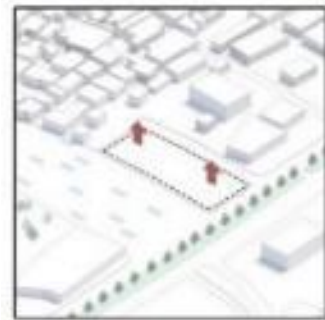

SITE CONTEXT

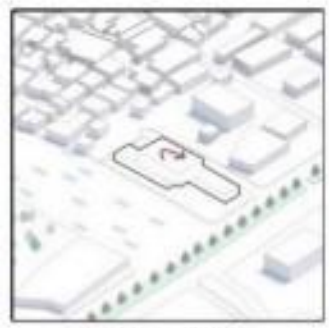

SPIN TO CONTEXT

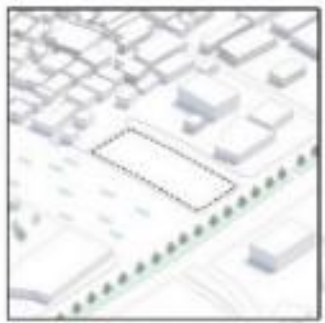

BASIC CEOMETRY

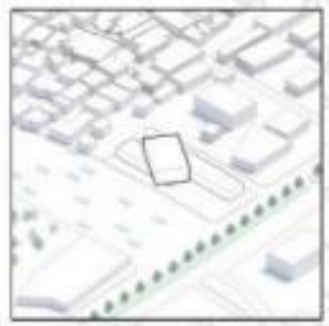

INSERTINC PROGRAMS

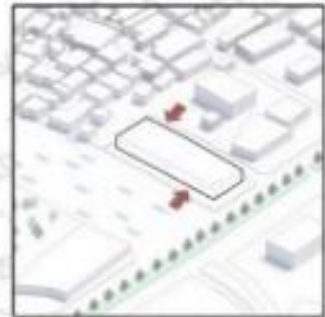

CUT OUT

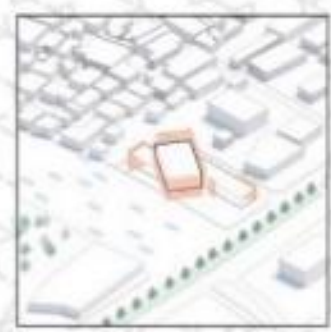

SECOND SKIN

Gambar 9. Diagram Proses Desain

Sumber: Penulis, 2020

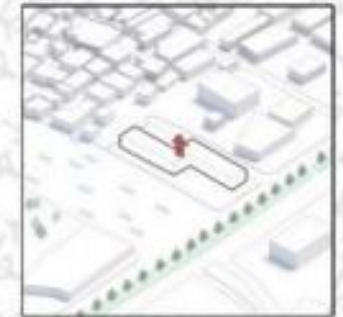

ADD MASS

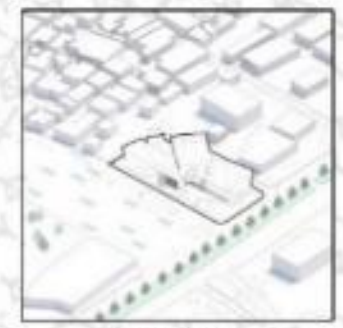

FINAL MASS

\section{Inovasi Desain Fasad Bangunan}

Pada fasad bangunan digunakan beberapa motif yang melambangkan nilai seni yang ada di Kawasan Senen ini, diantaranya:

a. Second Skin Batu Bata

Pada sisi Teater digunakan second skin batu bata dengan siluet beberapa adegan dalam wayang orang. 


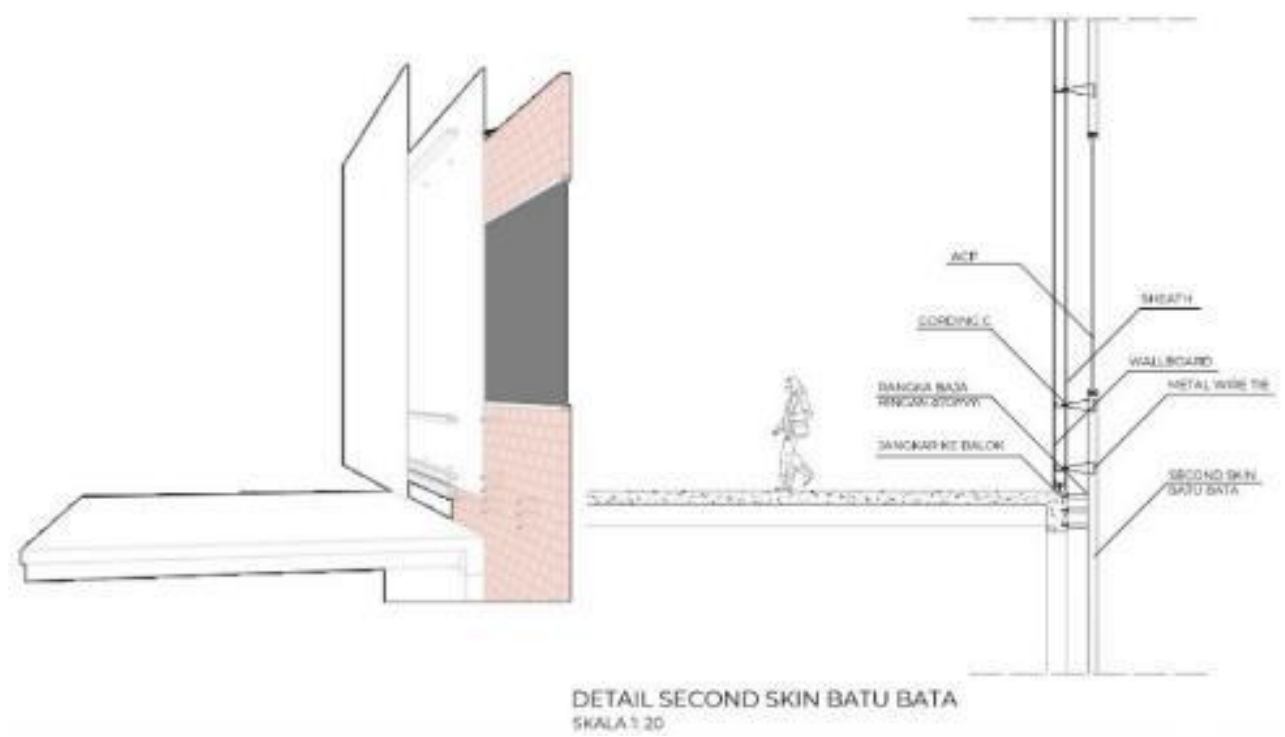

Gambar 10. Detail Second Skin Batu Bata

Sumber: Penulis, 2020

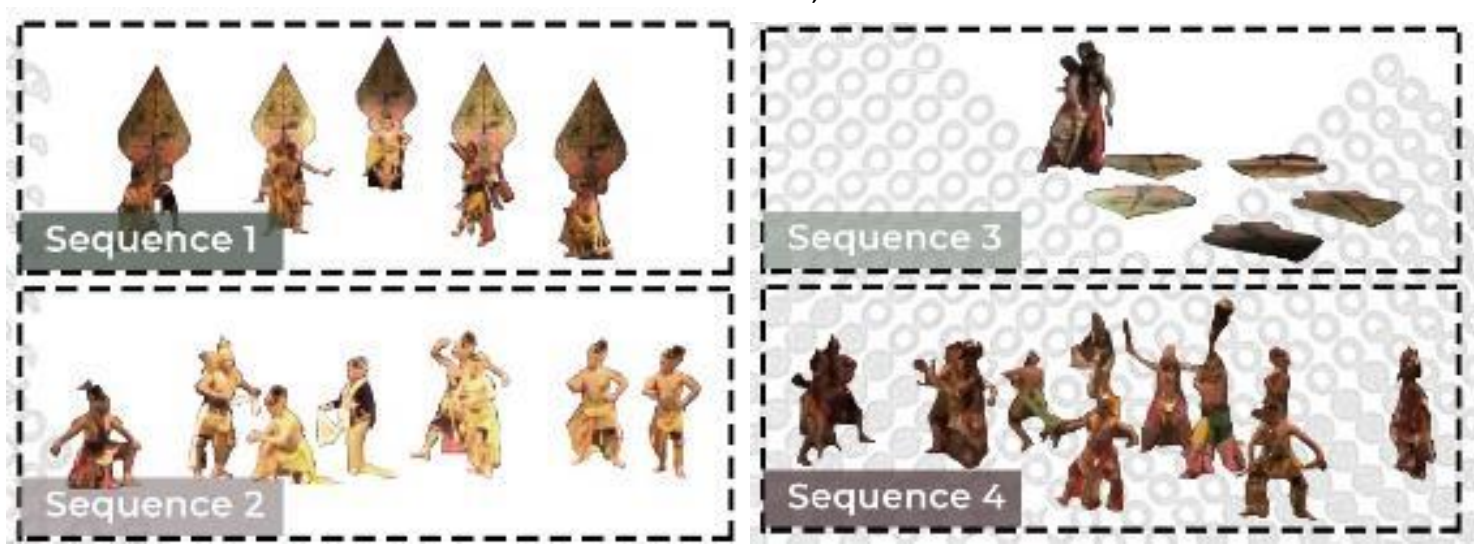

Gambar 11. Siluet Sequence Tarian Pada Fasad

Sumber: Penulis, 2020

b. Second Skin Batik

Beberapa bagian dari bangunan ditutupi oleh second skin bermotif batik yang bertujuan untuk menyaring Sebagian sinar matahari yang masuk ke bangunan. Motif batik yang digunakan merupakan motif batik gunungan yang melambangkan pembuka/penutup suatu babak pertunjukan, melambangkan pintu gerbang istana, dan menggambarkan keadaan dunia dan seisinya.
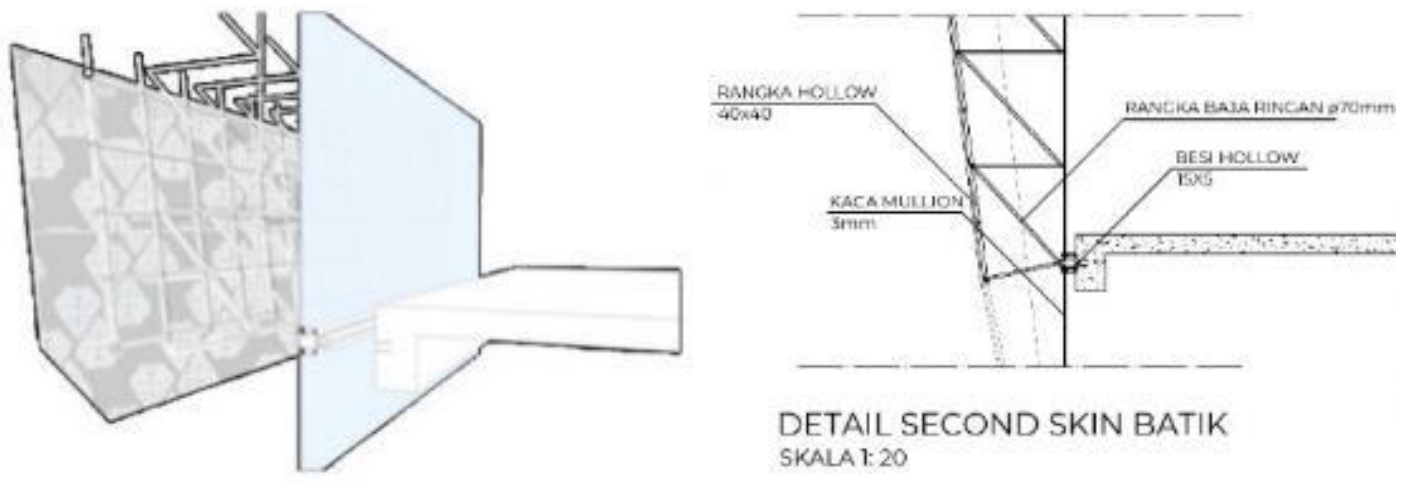

Gambar 12. Detail Second Skin Batik

Sumber: Penulis, 2020 


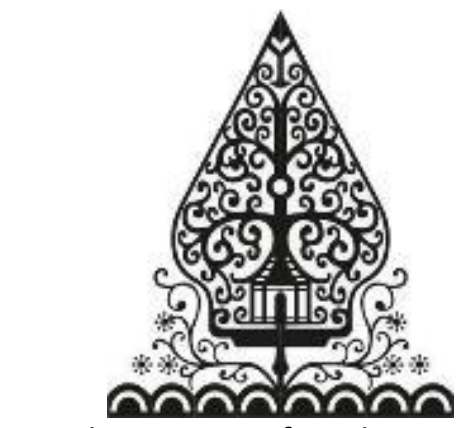

Gambar 13. Motif Batik Gunungan

Sumber: Pinterest

\section{ELEMEN BANGUNAN}

\section{AKSONOMETRI STRUKTUR}

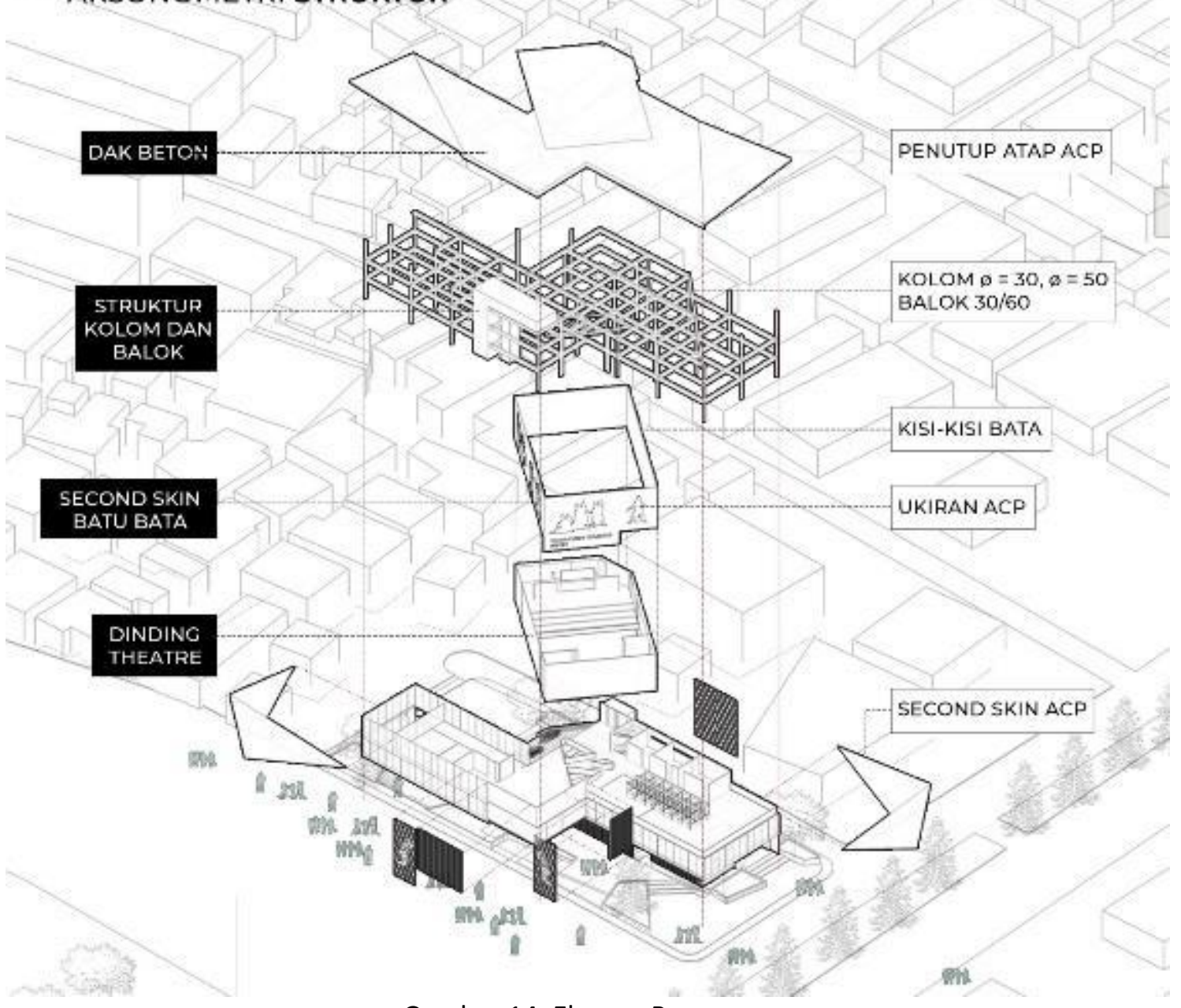

Gambar 14. Elemen Bangunan

Sumber: Penulis, 2020

\section{KESIMPULAN DAN SARAN}

\section{Kesimpulan}

Seiring dengan perkembangan jaman, manusia dipaksa untuk berevolusi dan mengembangkan dirinya untuk dapat menghadapi tantangan di kemudian hari. Dalam kasus ini, Kawasan Senen yang dahulu terkenal akan "Seniman Senen" nya sudah mulai kehilangan esensi seni itu sendiri. 
Oleh karena itu perancangan 3rd place dengan unsur seni ini harus mengkombinasi dan menciptakan tipologi baru yang berdasarkan dari aktivitas dan kebiasaan masyarakat zaman sekarang.

\section{Saran}

Agar proyek Wadah Seni Kolektif Senen ini dapat berfungsi dengan optimal, dibutuhkan peran dan kerjasama dengan pihak pemerintah dan juga pihak swasta untuk dapat mempromosikan serta, mendanai biaya pembangunan dan juga operasional proyek.

\section{REFERENSI}

Badan Pusat Statistik Provinsi DKI Jakarta. (2019). Kecamatan Senen Dalam Angka 2019. Jakarta: Badan Pusat Statistik Provinsi DKI Jakarta.

Biran, M. Y. (2008). Keajaiban di Pasar Senen. Jakarta: KPG.

Certeau, D. (1984). The Practice of Everyday Life.

Coates, N. (2012). Narrative Architecture. United Kingdom: Wiley

Lefebvre, H. (1991). The Critique of Everyday Life. New York: Verso

Merrillees, S. (2015). Jakarta: Portraits of a Capital 1950-1980. Jakarta: Equinox Publishing

Montgomerry, C. (2013). Happy City. Canada: Farrar

Oldenburg, R. (1997). The Great, Good Place. Cambridge: Da Capo Press florida

Project for Public Spaces. (2020). Retrieved January 22, 2020, from www.pps.org.

Putnam, R. (2000). Bowling Alone: The Collapse and Revival of American Community. United States: Simon \& Schuster.

Tuan, Y. F. (1977). Space and Place. United States: University of Minnesota Press. 